\title{
Synthesis and properties of novel network polymers containing castor oil and silsesquioxane moieties
}

\author{
Nozomu Uchida and Hiroaki Kouzai
}

Novel network polymer precursors were synthesized with castor oil or branched poly(L-lactic acid) and 3-(triethoxysilyl)propyl isocyanate. The network polymer precursors were cross-linked at $120^{\circ} \mathrm{C}$ for $24 \mathrm{~h}$ to obtain network polymer films. The film formed from castor oil was easily broken when peeled off of a polytetrafluoroethylene petri dish, while the film formed from branched poly(L-lactic acid) was obtained as a self-supporting film. Thermal stabilities of the obtained films were measured by thermogravimetric analysis. The temperature at which $10 \%$ weight loss $\left(T_{\mathrm{d} 10}\right)$ occurred was $298{ }^{\circ} \mathrm{C}$ for the film derived from castor oil, and the $T_{\mathrm{d} 10}$ of the film made from branched poly(L-lactic acid) was $200^{\circ} \mathrm{C}$. The film obtained using branched poly(L-lactic acid) exhibited elastomeric properties owing to a relatively low glass transition temperature of $3{ }^{\circ} \mathrm{C}$ and the onset of a rubbery plateau region at approximately $20^{\circ} \mathrm{C}$, as measured by dynamic mechanical analysis. Furthermore, we also prepared a film using the precursor material together with tetraethyl orthosilicate. The obtained film exhibited a higher thermal stability $\left(T_{\mathrm{d} 10}=223^{\circ} \mathrm{C}\right)$ than that of the film using branched poly(L-lactic acid). Finally, the cross-linked films were subjected to degradation by exposure to porcine pancreas lipase. The observation of weight loss after 30 days confirmed the degradability of the films.

Polymer Journal (2016) 48, 703-708; doi:10.1038/pj.2016.11; published online 17 February 2016

\section{INTRODUCTION}

Polymers derived from petroleum resources have been widely used in a broad range of applications in the form of elastomers, fibers, foams, coatings and biomedical materials owing to their high thermal stabilities, high durability and lightweight properties. In general, these polymers are not environmentally degradable because of their high chemical stability. As a result, polymer waste streams are currently subjected to thermal recycling by a combustion treatment process, which has led to increased carbon dioxide emissions and has become a point of contention for environmental issues, such as global warming. Consequently, biomass-derived polymers have gained the attention of many researchers in recent years as environmentally friendly materials. ${ }^{1-12}$ The use of biomass polymers is expected to make a significant contribution toward reduction of carbon dioxide emissions because biomass is a renewable resource. However, the majority of general biomass polymers are typically hard and brittle plastics, poly(L-lactic acid) (PLLA) being a well-known example. Accordingly, polymers that exhibit these properties are only useful for a narrow range of applications. In this study, we therefore focused on the use of castor oil to address the problem of low elasticity in biodegradable polymers. Castor oil is a polyol obtained from Ricinus communis seeds, and polymers derived from castor oil are highly flexible by virtue of the incorporation of long aliphatic chains. ${ }^{13-18}$ For this reason, castor oil is a suitable material for the modification of brittle polymers. Research on polymers derived from castor oil has generally focused on utilizing its hydroxyl groups to synthesize polyurethanes. It is important to explore the use of castor oil for the synthesis of novel polymers beyond simply polyurethanes, however, to realize the potential of biomass polymers for various applications. Cross-linked polymers are tough and exhibit elastomeric properties. We have already reported a novel network polymer using branched PLLA derived from castor oil and 2-acryloyloxyethyl isocyanate. ${ }^{19}$ Although biomass polymers prepared using castor oil contribute toward reducing the environmental impact of polymers as described above, they tend to be poorly thermally stable, limiting their practical utility. To address this problem, we envisioned combining the biodegradability of biomass polymers with the desirable properties of siliconbased polymers to form high-performance silicon-based hybrid polymers. Polymers containing inorganic elements are known to exhibit desirable or useful properties. ${ }^{20-24}$ For example, polymers containing Si moieties generally have a high thermal stability as well as highly adhesive properties. Among such polymers, polysilsesquioxane has been studied by many groups. ${ }^{25-34}$ This is because these polymers can be synthesized by simple methods using silane coupling agents. Moreover, polysilsesquioxanes have already been commercialized for applications, such as low pollution paints and hard coatings.

Accordingly, we carried out the synthesis and characterization of a novel network polymer using castor oil and 3-(triethoxysilyl)propyl isocyanate with the goal of developing a high-performance biomass 
polymer. Furthermore, the degradability of the synthesized polymers was confirmed by enzyme hydrolysis.

\section{EXPERIMENTAL PROCEDURE}

\section{Materials}

Castor oil (hydroxyl value $=161.2 \mathrm{mg} \mathrm{KOH}$ per gram) was a gift from Itoh Oil Chemicals (Japan). The number-average molecular weight of castor oil was 950 (determined by gel permeation chromatography). The structure of castor oil was confirmed by ${ }^{1} \mathrm{H}$ NMR spectroscopy. The chemical shifts are assigned as follows: ${ }^{1} \mathrm{H}$ NMR ( $\delta$, p.p.m. from tetramethylsilane (TMS) in $\mathrm{CDCl}_{3}$ ): 0.9 $\left(\mathrm{t},-\mathrm{CH}_{2} \mathrm{CH}_{3}\right), 1.3\left(\mathrm{~m},-\mathrm{CH}_{2} \mathrm{CH}_{2} \mathrm{CH}_{2}-\right), 1.4\left(\mathrm{~m},-\mathrm{CH}_{2} \mathrm{CH}_{2} \mathrm{CH}_{2}-\right), 1.6$ $\left(\mathrm{m},-\mathrm{CH}_{2} \overline{\mathrm{CH}}_{2} \mathrm{CH}_{2}-\right), 2.0\left(\mathrm{t},-\overline{-\mathrm{CH}_{2}} \mathrm{CH}=\mathrm{CH}-\right), 2.2\left(\mathrm{t},=\overline{\mathrm{CH}} \mathrm{CH}_{2} \mathrm{CH}\right.$ $\left.(\mathrm{OH})-), 2.3 \overline{(\mathrm{q}},-\mathrm{C}(\mathrm{O}) \mathrm{CH}_{2} \mathrm{CH}_{2-}\right), 3.6\left(\mathrm{~m},-\mathrm{CH}_{2} \mathrm{CH}(\mathrm{OH}) \mathrm{CH}_{2-}\right), 4.1$ $\left(\mathrm{m},-\mathrm{CH}(\mathrm{OH}) \mathrm{CH}_{2} \mathrm{CH}_{2}\right), 4.3\left(\mathrm{~m},-\mathrm{CH} \mathrm{CH}_{2} \mathrm{O}-\right), \overline{5} .2\left(\mathrm{~m},-\mathrm{CH}_{2} \mathrm{CH}\right.$ $\left.\left(\mathrm{O} \mathrm{C} \mathrm{O} \mathrm{CH} 2^{-}\right) \quad \overline{\mathrm{CH}_{2}}-\right), 5.4(\mathrm{~m},-\mathrm{CH}=\mathrm{CH}-), 5.6(\mathrm{~m},-\mathrm{CH}=\mathrm{CH}-)$. The

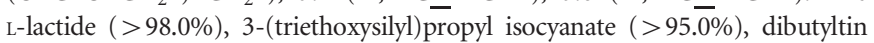
dilaurate $(>95.0 \%)$, tetraethyl orthosilicate $(>96.0 \%)$ and porcine pancreas lipase were purchased from Tokyo Chemical Industry (Tokyo, Japan). Disodium hydrogen phosphate $(>99.0 \%)$ and potassium dihydrogen phosphate (>99.0\%) were purchased from Wako Pure Chemical Industries (Osaka, Japan). Tin 2-ethylhexanoate $(>92.5 \%)$ was purchased from Sigma-Aldrich Japan (Tokyo, Japan). All the other reagents and solvents are commercially available and were used as received.

\section{Synthesis of branched PLLA (COLA) (1)}

COLA was synthesized according to ref. 19. All synthetic routes are shown in Figure 1. A typical process is described as follows: castor oil $(1.9 \mathrm{~g}, 2.0 \mathrm{mmol})$ was reacted with L-lactide $(5.8 \mathrm{~g}, 40.0 \mathrm{mmol})$ for $5 \mathrm{~h}$ at $140{ }^{\circ} \mathrm{C}$ in the presence of tin 2-ethylhexanoate as a catalyst under a nitrogen atmosphere. After completion of the reaction, the product was precipitated into hexane and dried under vacuum.

${ }^{1} \mathrm{H}$ NMR $\left(\delta\right.$, p.p.m. from TMS in $\left.\mathrm{CDCl}_{3}\right): 0.9\left(\mathrm{t},-\mathrm{CH}_{2} \mathrm{CH}_{3}\right), 1.3\left(\mathrm{~m},-\mathrm{CH}_{2}\right.$ $\left.\mathrm{CH}_{2} \mathrm{CH}_{2}-\right), 1.4\left(\mathrm{~m},-\mathrm{CH}_{2} \mathrm{CH}_{2} \mathrm{CH}_{2}-\right), 1.6\left(\mathrm{~m},-\mathrm{CH}_{2} \mathrm{CH}_{2} \overline{\mathrm{CH}}_{2-},-\mathrm{CH}-\mathrm{CH}_{3}\right)$, $2.0\left(\mathrm{t},-\mathrm{CH}_{2} \mathrm{CH}=\mathrm{CH}-\right), 2.3\left(\mathrm{q},-\mathrm{C}(\mathrm{O}) \mathrm{CH}_{2} \mathrm{CH}_{2}-\right), 4.1(\mathrm{~m},-\mathrm{CH}(\mathrm{O} \mathrm{C} \mathrm{O}-)$ $\left.\left.\mathrm{CH}_{2} \mathrm{CH}_{2-}\right), 4.3\left(\mathrm{~m},-\mathrm{CH} \mathrm{CH} \mathrm{CH}_{2} \mathrm{O}\right), 4.9 \overline{(\mathrm{m},}-\mathrm{CH}_{2} \mathrm{CH}(\mathrm{O} \mathrm{C} \mathrm{O}-) \mathrm{CH}_{2}-\right)$, $5 . \overline{1-5} .2\left(\mathrm{~m},-\mathrm{CH}_{2} \mathrm{CH}\left(\mathrm{O} \mathrm{C} \mathrm{O} \overline{\mathrm{CH}_{2}-}\right) \mathrm{CH}_{2}-,-\mathrm{O} \mathrm{C}(\mathrm{O}) \overline{\mathrm{CH}}\left(\mathrm{CH}_{3}\right) \mathrm{C}(\mathrm{O})-\right), 5.4$ $(\mathrm{m},-\mathrm{CH}=\mathrm{CH}-), 5 . \overline{6}(\mathrm{~m},-\mathrm{CH}=\underline{\mathrm{CH}}-)$.

\section{Synthesis of castor oil-modified triethoxysilane (CO-TES) (2)}

Under an argon atmosphere, 3-(triethoxysilyl)propyl isocyanate $(0.74 \mathrm{~g}$, $3.0 \mathrm{mmol})$ and castor oil $(0.95 \mathrm{~g}, 1.0 \mathrm{mmol})$ were dissolved in chloroform $\left(\mathrm{CHCl}_{3}\right)(2.0 \mathrm{ml})$. The solution was stirred at room temperature for $0.5 \mathrm{~h}$, and dibutyltin dilaurate, which was used as a catalyst, was added dropwise. The mixture was stirred for $24 \mathrm{~h}$, at which point the solvent was evaporated, and the product was washed with hexane and dried under vacuum.
${ }^{1} \mathrm{H}$ NMR ( $\delta$, p.p.m. from TMS in $\mathrm{CDCl}_{3}$ ) 0.6 (q, $\left.-\mathrm{CH}_{2} \mathrm{CH}_{2} \mathrm{Si}-\right), 0.9$ (t, $-\mathrm{CH}_{2} \mathrm{CH}_{3}$ ), $1.3-1.6\left(\mathrm{~m},-\mathrm{CH}_{2} \mathrm{CH}_{2} \mathrm{CH}_{2}-,-\mathrm{Si} \mathrm{CH}_{2} \mathrm{CH}_{3}\right), \overline{2.0}\left(\mathrm{t},-\mathrm{CH}_{2}\right.$ $\mathrm{CH}=\mathrm{CH}-), 2.3\left(\mathrm{q},-\mathrm{C}(\mathrm{O}) \mathrm{CH}_{2} \mathrm{CH}_{2}-\right), 3.2\left(\mathrm{t},-\mathrm{C}(\mathrm{O}) \mathrm{NH} \overline{\mathrm{CH}_{2}-}\right), 3.8(\mathrm{~m},-\mathrm{Si}$ $\left.\mathrm{O} \mathrm{CH}_{2} \mathrm{CH}_{3}\right), 4.1\left(\mathrm{~m},-\mathrm{CH}(\mathrm{O} \mathrm{C} \mathrm{O}-) \mathrm{CH}_{2} \mathrm{CH}_{2}-\right), 4.3\left(\mathrm{~m},-\mathrm{CH} \mathrm{CH} \mathrm{CH}_{2}\right)$, $4.9\left(\overline{\mathrm{m}},-\mathrm{CH}_{2} \mathrm{CH}(\mathrm{O} \mathrm{C} \mathrm{O}-) \mathrm{CH}_{2}-\right), 5.2\left(\overline{\mathrm{m},}-\mathrm{CH}_{2} \mathrm{CH}\left(\mathrm{O} \mathrm{C} \mathrm{O} \mathrm{CH}_{2}-\right) \mathrm{CH}_{2^{-}}\right)$, $5.4(\mathrm{~m},-\underline{\mathrm{CH}}=\overline{\mathrm{CH}}-), 5.6(\mathrm{~m},-\mathrm{CH}=\underline{\mathrm{CH}}-)$.

\section{Synthesis of COLA-modified triethoxysilane (COLA-TES) (3)}

3 -(Triethoxysilyl)propyl isocyanate $(0.14 \mathrm{~g}, 0.6 \mathrm{mmol})$ and COLA (1.14 g, $0.2 \mathrm{mmol})$ were dissolved in $\mathrm{CHCl}_{3}(2.0 \mathrm{ml})$. The solution was stirred at room temperature for $0.5 \mathrm{~h}$, and dibutyltin dilaurate, which was used as a catalyst, was added dropwise. The mixture was stirred for $24 \mathrm{~h}$, at which point the solvent was evaporated, and the product was washed with hexane and dried under vacuum.

${ }^{1} \mathrm{H}$ NMR ( $\delta$, p.p.m. from TMS in $\left.\mathrm{CDCl}_{3}\right): 0.6\left(\mathrm{q},-\mathrm{CH}_{2} \mathrm{CH}_{2} \mathrm{Si}-\right), 0.9$ (t, $\left.-\mathrm{CH}_{2} \mathrm{CH}_{3}\right), 1.2-1.5\left(\mathrm{~m},-\mathrm{CH}_{2} \mathrm{CH}_{2} \mathrm{CH}_{2}-,-\mathrm{Si} \mathrm{CH}_{2} \mathrm{CH}_{3}\right), 1 . \overline{6}\left(\mathrm{~m},-\mathrm{CH}_{2}\right.$ $\left.\mathrm{CH}_{2} \mathrm{CH}_{2}-,-\mathrm{CH} \mathrm{CH} \mathrm{CH}_{3}\right), 2.0\left(\mathrm{t},-\mathrm{CH}_{2} \overline{\mathrm{CH}}=\mathrm{CH}-\right), 2.3\left(\mathrm{q},-\mathrm{C}(\mathrm{O}) \mathrm{CH}_{2} \mathrm{CH}_{2}-\right)$, $3.2\left(\mathrm{t},-\mathrm{C}(\mathrm{O}) \mathrm{N} \underline{\mathrm{H}} \overline{\mathrm{CH}_{2}}-\right), 3.8\left(\overline{\mathrm{m}},-\mathrm{Si} O \mathrm{CH}_{2} \mathrm{CH}_{3}\right), 4.1\left(\mathrm{~m},-\mathrm{CH} \overline{(\mathrm{OH})} \mathrm{CH}_{2}\right.$ $\left.\mathrm{CH}_{2}-\right), 4.2-4.4\left(\overline{\mathrm{m}},-\mathrm{CH} \mathrm{CH}_{2} \mathrm{O}-\right), 4.9\left(\mathrm{~m},-\overline{-\mathrm{CH}} \mathrm{CH}_{2}(\mathrm{O} \mathrm{C} \mathrm{O}-) \mathrm{CH}_{2}-\right), 5.1-\overline{5.2}$ $\left(\mathrm{m},-\mathrm{CH}_{2} \mathrm{CH}\left(\mathrm{O} \mathrm{C} \mathrm{O} \overline{\mathrm{CH}}_{2}-\right) \mathrm{CH}_{2-},-\mathrm{O} \mathrm{C}(\mathrm{O}) \mathrm{CH}\left(\mathrm{CH}_{3}\right) \mathrm{C}(\mathrm{O})-\right), 5.3$ $(\mathrm{m},-\underline{\mathrm{CH}}=\mathrm{C} \overline{\mathrm{H}}-), 5.5(\mathrm{~m},-\mathrm{CH}=\underline{\mathrm{CH}}-)$.

\section{Cross-linking reaction of CO-TES (Film 1)}

CO-TES $(0.95 \mathrm{~g}, 1.0 \mathrm{mmol})$ was dissolved in tetrahydrofuran $(1.0 \mathrm{ml})$. Pure water and triethylamine as a catalyst were added dropwise into the solution. The mixture was then dried and cured at $40{ }^{\circ} \mathrm{C}$ for $3 \mathrm{~h}$ in a polytetrafluoroethylene (PTFE) petri dish. Further cross-linking was carried out at $120^{\circ} \mathrm{C}$ for $24 \mathrm{~h}$. The cross-linked film was dipped in organic solvent to wash and dried under vacuum.

Fourier transform infrared (FT-IR) spectroscopy $\left(\mathrm{ATR}, \mathrm{cm}^{-1}\right): 3350$ (-NH-), $2940\left(-\mathrm{CH}_{2}-\right), 1750$ (-CO-O-).

\section{Cross-linking reaction of COLA-TES (Film 2)}

The cross-linking of COLA-TES was performed in the same way as Film 1. Briefly, COLA-TES (1.0 g, $0.2 \mathrm{mmol})$ was dissolved in tetrahydrofuran $(1.0 \mathrm{ml})$. Pure water and triethylamine as a catalyst were added dropwise to the solution. The mixture was then dried and cured at $40{ }^{\circ} \mathrm{C}$ for $3 \mathrm{~h}$ in a PTFE petri dish. Further cross-linking was carried out at $120^{\circ} \mathrm{C}$ for $24 \mathrm{~h}$. The cross-linked film was dipped in organic solvent to wash and dried under vacuum. FT-IR (ATR): 3320 (-NH-), $2920\left(-\mathrm{CH}_{2}-\right), 1750$ (-CO-O-) $\mathrm{cm}^{-1}$.

\section{Cross-linking reaction of COLA-TES and tetraethyl orthosilicate} (Film 3)

We also carried out the cross-linking reaction using tetraethyl orthosilicate, which resulted in an increased number of inorganic moieties in the film
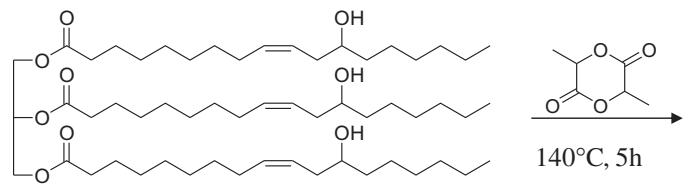

$140^{\circ} \mathrm{C}, 5 \mathrm{~h}$

Castor oil

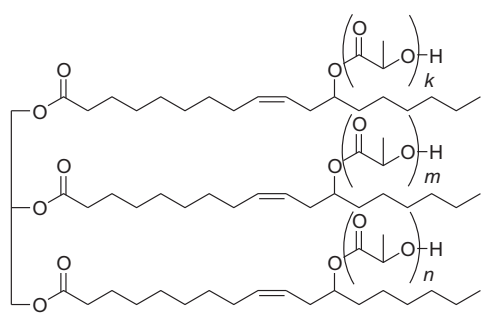

(1)

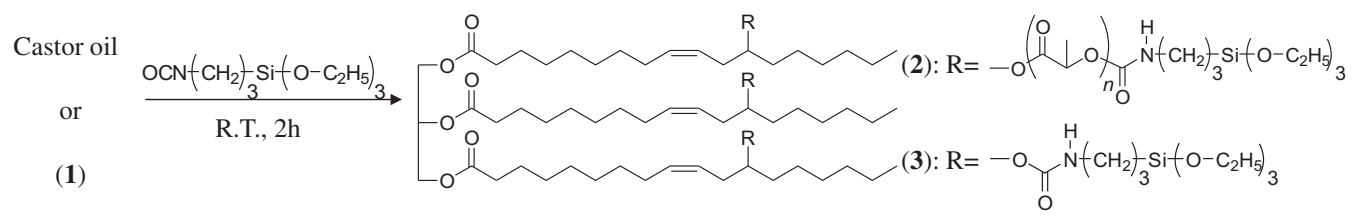

Figure 1 Synthesis of COLA (1), CO-TES (2) and COLA-TES (3). 
compared with the above method. COLA-TES ( $1.0 \mathrm{~g}, 0.2 \mathrm{mmol})$ and tetraethyl orthosilicate $(0.2 \mathrm{~g}, 1.0 \mathrm{mmol})$ were dissolved of tetrahydrofuran $(1.0 \mathrm{ml})$. Pure water and triethylamine as a catalyst were added dropwise to the solution. The mixture was then dried and cured at $40^{\circ} \mathrm{C}$ for $3 \mathrm{~h}$ in a PTFE petri dish. Further cross-linking was carried out at $120^{\circ} \mathrm{C}$ for $24 \mathrm{~h}$. The cross-linked film was dipped in organic solvent to wash, and dried under vacuum. FT-IR $\left(\right.$ ATR, $\left.\mathrm{cm}^{-1}\right)$ : $3500(-\mathrm{NH}-), 2940\left(-\mathrm{CH}_{2}-\right), 1750$ (-CO-O-).

\section{Enzyme degradation of cross-linked films}

To investigate the biodegradability of the cross-linked films, we performed enzymatic degradation of the obtained products using porcine pancreas lipase. The enzymatic degradation reaction was carried out for 30 days under suitable conditions (for example, phosphate buffer of $\mathrm{pH}$ 8.2) using porcine pancreas lipase. The specific methods are described below.

First, phosphate buffer was prepared by combining disodium hydrogen phosphate $(8.95 \mathrm{~g})$, potassium dihydrogen phosphate $(0.91 \mathrm{~g})$ and pure water (500 ml). Cross-linked films were cut into $1.0 \mathrm{~cm}^{2}$ squares. The samples were weighed and dipped into the freshly prepared phosphate-buffered solution $(30 \mathrm{ml})$ for $24 \mathrm{~h}$ in an Erlenmeyer flask equipped with a lid. The porcine pancreas lipase (1.0 g, 20 units) was then added to the flask and shaken for 30 days at $37^{\circ} \mathrm{C}$. At this point, the products were washed with pure water, dried under vacuum and weighed.

\section{Measurements}

Infrared absorption spectra (FT-IR) were measured using a JASCO FT/IR-615 instrument. ${ }^{1} \mathrm{H}$ NMR spectra were obtained using a MERCURY plus $400 \mathrm{MHz}$ instrument by Varian Technologies Japan (Tokyo, Japan). NMR data are expressed in p.p.m. units relative to internal TMS. Molecular weights of the polymer were determined by gel permeation chromatography (GPC). Polystyrene was used as a calibration standard. GPC measurements were carried out with an HLC-8220 instrument (Tosoh, Tokyo, Japan) using a TSKgel Super HM-M column and DMF ( $N, N$-dimethylformamide) as solvent/eluent. X-ray diffraction analysis was performed using a Rigaku (Tokyo, Japan) X-ray diffractometer. Stress-strain curves were measured at room temperature using an EZ-L $1.0 \mathrm{kN}$ instrument by Shimadzu (Kyoto, Japan). Thermogravimetric analysis was conducted in air or nitrogen atmosphere using a Rigaku Thermoplus TG 8120 at a heating rate of $10.0{ }^{\circ} \mathrm{C} \mathrm{min}^{-1}$. The nitrogen flow was measured at $100 \mathrm{ml} \mathrm{min}^{-1}$. DSC (differential scanning calorimetry) was performed using a Rigaku Thermoplus DSC 8230 at a heating rate of $10.0^{\circ} \mathrm{C} \mathrm{min}-1$. Dynamic mechanical analysis was performed on a DDV-GP instrument (A \& D, Tokyo, Japan). Dynamic mechanical analysis measurements were carried out over four frequencies $(1.0 \mathrm{~Hz}, 5.0 \mathrm{~Hz}, 10.0 \mathrm{~Hz})$ at a heating rate of $2.0^{\circ} \mathrm{C} \mathrm{min}^{-1}$.

\section{RESULTS AND DISCUSSION}

\section{Synthesis of COLA (1)}

The yield of COLA was $6.43 \mathrm{~g}(82 \%)$, and the product was soluble in common organic solvents, such as methanol, $\mathrm{CHCl}_{3}$, and DMF; however, it was insoluble in hexane and water. The molecular weight and molecular weight distribution $\left(M_{\mathrm{w}} / M_{\mathrm{n}}\right)$ of COLA were determined by GPC. The number-average molecular weight $\left(M_{\mathrm{n}}\right)$ and weight-average molecular weight $\left(M_{\mathrm{w}}\right)$ of COLA were determined to be 5320 and $6420\left(M_{\mathrm{w}} / M_{\mathrm{n}}=1.20\right)$, respectively. The structure of the product was confirmed by ${ }^{1} \mathrm{H}$ NMR spectroscopy. Peaks attributable to castor oil's alkyl group were found at 0.9 p.p.m. and 1.2-1.4 p.p.m. Furthermore, peaks attributable to the methyl and methine protons of PLLA, formed by the reaction of L-lactide with castor oil, were observed at 1.4-1.7 p.p.m. and 5.2 p.p.m., respectively. The castor oil methine peak at 3.5 p.p.m. disappeared, and a new peak at 4.9 p.p.m. appeared, confirming esterification of the castor oil. Accordingly, the products confirmed the structure of COLA. These results were identical with those observed in a previous study. ${ }^{19}$
Synthesis of products containing triethoxysilyl groups (2) and (3) CO-TES and COLA-TES were obtained in high yield (>95\%). The products, both of which contain a triethoxysilyl group, exhibited similar solubility in organic solvents as COLA; both were also insoluble in hexane and water. The structures of both products were confirmed by ${ }^{1} \mathrm{H}$ NMR spectroscopy. The peaks for castor oil and COLA were confirmed. The peaks of the alkyl group of 3-(triethoxysilyl)propyl isocyanate were observed at 0.6 p.p.m. Moreover, peaks attributable to the methylene protons in the ethoxy group were confirmed at 3.8 p.p.m. The $-\mathrm{NH}$ - peaks derived from the urethane group were observed at 3.2 p.p.m. (Figure 2).

\section{Preparation of cross-linked films}

Cross-linked CO-TES (Film 1) was obtained as a colorless film in $61 \%$ yield. The film was easily broken when peeled off of the PTFE petri dish. Cross-linked COLA-TES (Film 2) was obtained as a white, selfsupporting film in $57 \%$ yield. The cause of the coloration in Film 2 is presumably due to the crystalline moieties formed from the L-lactide segments. The film prepared using COLA-TES and tetraethyl orthosilicate (Film 3) was also white and self-supporting, which is in contrast to Film 1, and it was obtained in $71 \%$ yield. The coloration of Film 3 was similar to that of Film 2. The X-ray diffraction spectra of Film 2 and Film 3 both exhibited a characteristic peak at $2 \theta=16.5^{\circ}$, which was assigned to the presence of crystalline PLLA. ${ }^{6}$ The crystallinity of the films was calculated using the following equation (1):

$$
\text { Crystallinity }(\%)=\frac{I_{\mathrm{c}}}{I_{\mathrm{c}}+I_{\mathrm{a}}} \times 100
$$

where $I_{\mathrm{c}}$ represents the integrated intensity of the crystalline peaks and $I_{\mathrm{a}}$ represents the integrated intensity of the amorphous peaks. The crystallinity of Films 2 and 3 were calculated as 64 and 49\%, respectively. Both films were found to be insoluble in organic solvents, likely due to the cross-linked nature of the products. FT-IR spectroscopy was used to estimate the molecular structure of the products. A signal at $3300 \mathrm{~cm}^{-1}-3500 \mathrm{~cm}^{-1}$ in all the three films confirmed the presence of $-\mathrm{NH}$ - moieties derived from the formation of urethane groups. Furthermore, a signal attributable to the amide $\mathrm{NH}$ was observed at $1530 \mathrm{~cm}^{-1}$ in the IR spectra of all the three films. The peak at $1100 \mathrm{~cm}^{-1}$ was attributed to the siloxane group, indicating the formation of polysilsesquioxane. The FT-IR spectrum of Film 2 is shown Figure 3.

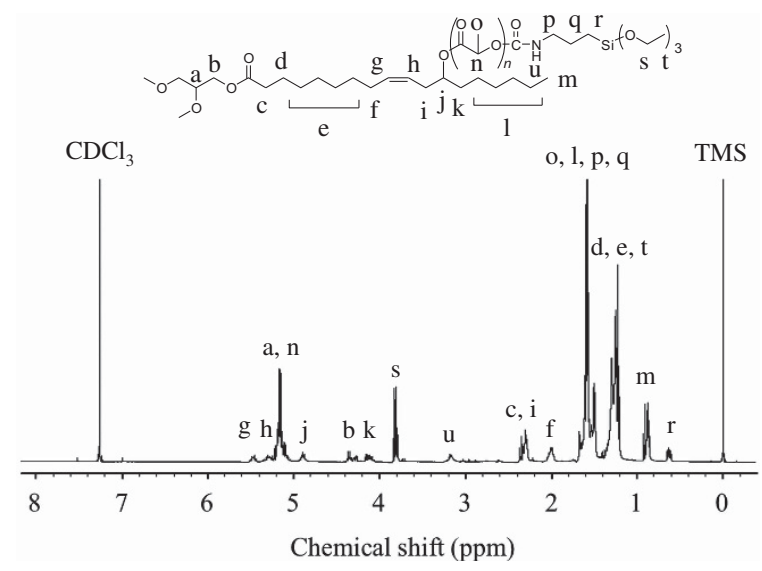

Figure $2{ }^{1} \mathrm{H}$ NMR spectrum of COLA-TES (3) in $\mathrm{CDCl}_{3}$. 


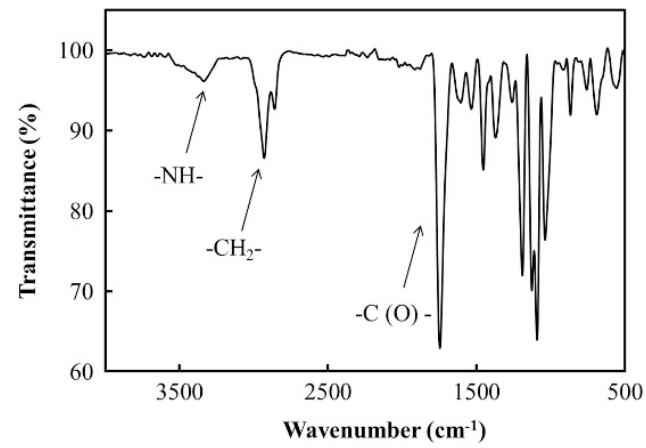

Figure 3 Fourier transform infrared spectrum of Film 2.

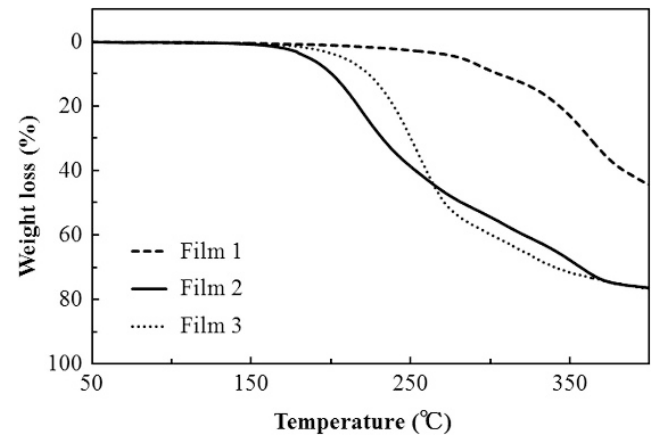

Figure 4 Thermogravimetric analysis curves of Film 1, Film 2 and Film 3 at a heating rate of $10{ }^{\circ} \mathrm{C} \mathrm{min}-1$ under a nitrogen atmosphere.

\section{Thermal properties}

To determine the thermal stability of the samples, thermogravimetric analysis was carried out under both nitrogen and air atmospheres. Figure 4 shows the thermogravimetric analysis curves for Films 1, 2 and 3 obtained under a nitrogen atmosphere. For Film 1, the temperature at which $5 \%$ weight loss occurred $\left(T_{\mathrm{d} 5}\right)$ was $275^{\circ} \mathrm{C}$, and the temperature at which $10 \%$ weight loss occurred $\left(T_{\mathrm{d} 10}\right)$ was $298^{\circ} \mathrm{C}$. For Film 2, the $T_{\mathrm{d} 5}$ and $T_{\mathrm{d} 10}$ were 186 and $200^{\circ} \mathrm{C}$, respectively. In addition, the melting temperature of the crystalline domain of Film 2 was observed at $133.2^{\circ} \mathrm{C}$ in the DSC measurement. For Film 3, a $T_{\mathrm{d} 5}$ of $208^{\circ} \mathrm{C}$ and a $T_{\mathrm{d} 10}$ of $223^{\circ} \mathrm{C}$ was observed, and a melting temperature of the crystalline domain was observed at $127.9^{\circ} \mathrm{C}$ in the DSC measurement. The thermal stabilities of the samples under an air atmosphere were similar to those measured under nitrogen protection (Table 1). In descending order, the thermal stabilities of the three films were found to be: Film $1>$ Film $3>$ Film 2 . The thermal stability of the films is influenced by the L-lactide segment, which is sensitive to thermal degradation, as well as the inorganic content. For instance, Film 1 exhibited a higher thermal stability than Film 2 because Film 1 lacks L-lactide segments. The relatively low degradation temperature of Film $2\left(T_{\mathrm{d} 5}=190^{\circ} \mathrm{C}\right)$ was presumably caused by network imperfections along the COLA side chain. Film 3 was more thermally stable than Film 2 because Film 3 has a higher inorganic content than Film 2.

\section{Mechanical properties}

We sought to further examine the mechanical properties of Films 2 and 3 upon observation that these samples peeled off easily from the PTFE petri dish. Presumably, Films 2 and 3 were able to be peeled from the PTFE petri dish because the interaction of the incorporated
Table 1 Thermal stability of cross-linked films

\begin{tabular}{llll}
\hline Compounds & Atmosphere & $\begin{array}{c}\mathrm{T}_{d 5^{\mathrm{a}}} \\
\left({ }^{\circ} \mathrm{C}\right)\end{array}$ & $\begin{array}{c}\mathrm{T}_{d 10^{\mathrm{a}}} \\
\left({ }^{\circ} \mathrm{C}\right)\end{array}$ \\
\hline Film 1 & Air & 268 & 292 \\
\multirow{3}{*}{ Film 2 } & $\mathrm{N}_{2}$ & 275 & 298 \\
& Air & 182 & 197 \\
Film 3 & $\mathrm{N}_{2}$ & 186 & 200 \\
& Air & 207 & 221 \\
& $\mathrm{~N}_{2}$ & 208 & 223 \\
\hline
\end{tabular}

aDetermined by thermogravimetric analysis measured at a heating rate $10{ }^{\circ} \mathrm{C} \mathrm{min}^{-1}$.

L-lactide segments increased their toughness. Thus, the mechanical properties of the films were further evaluated by stress-strain analysis. Figure 5 shows the stress-strain curves for Films 2 and 3. For Film 2, the tensile strength at break $\left(T_{\mathrm{B}}\right)$ was $1.92 \mathrm{MPa}$, and the elongation at break $\left(E_{\mathrm{B}}\right)$ was $61.2 \%$. The Young's modulus $(E)$ of Film 2 was $3.41 \mathrm{MPa}$. For Film 3, $T_{\mathrm{B}}, E_{\mathrm{B}}$ and $E$ were determined to be $0.28 \mathrm{MPa}$, $23.1 \%$ and $2.62 \mathrm{MPa}$, respectively. Overall, the mechanical strength of Film 3 was lower than Film 2. We hypothesized that the presence of the silsesquioxane moiety served to lower the crystallization of L-lactide segments, thereby leading to a decrease in mechanical strength. ${ }^{34}$

We subsequently measured the dynamic viscoelastic properties of both films by dynamic mechanical analysis. Figure 6 shows the temperature dependence of storage modulus $\left(E^{\prime}\right)$, loss modulus $\left(E^{\prime \prime}\right)$ and loss tangent $(\tan \delta)$ of Film 2 at $1.0 \mathrm{~Hz}$. The onset of the rubbery plateau region in $E^{\prime}$ of Film 2 was observed at $20^{\circ} \mathrm{C}$. This confirmed the stable elasticity of Film 2 at higher temperatures. Film 3 could not be measured at $-100^{\circ} \mathrm{C}$ and was therefore measured at $-50^{\circ} \mathrm{C}$. The rubbery plateau region in the $E^{\prime}$ of Film 3 began at $15^{\circ} \mathrm{C}$; however, Film 3 was broken at $90^{\circ} \mathrm{C}$. The reason for Film 3 breakage at both high and low temperature was considered to be caused by its low strength due to its silica content. The glass transition temperature $\left(T_{\mathrm{g}}\right)$ of Film 2 was observed at $3{ }^{\circ} \mathrm{C}$, while the $T_{\mathrm{g}}$ of Film 3 was observed at $-8^{\circ} \mathrm{C}$. The $T_{\mathrm{g}} \mathrm{s}$ of both the samples were similar to that of a branched PLLA-based polymer film $\left(T_{\mathrm{g}}=-5^{\circ} \mathrm{C}\right) .{ }^{19}$ These results suggest that both the samples are elastomers at room temperature.

\section{Enzyme degradability}

Weight loss (\%), GPC and ${ }^{1} \mathrm{H}$ NMR spectra were measured for the films after a degradation period of 30 days. GPC measurements and ${ }^{1} \mathrm{H}$ NMR spectroscopy were carried out on the soluble portions of the samples. The weight loss (\%) values, as well as the molecular weights of the degraded products as obtained by GPC, are shown in Table 2. The value of weight loss (\%) was calculated using the following equation (2):

$$
\text { Weightloss }(\%)=\frac{W_{0}-W_{30}}{W_{0}} \mathrm{~g} \times 100
$$

where $W_{0}$ represents the initial sample weight, and $W_{30}$ represents the degraded sample weight.

The degradability of the films was thought to be caused by the L-lactide segments because Film 1, which does not contain any L-lactide, was not degraded. The degradability of Film 2 was similar to that of the branched PLLA-based polymer film (weight loss $=8.4 \%) .{ }^{19}$ We also carried out control experiments in the absence of lipase to evaluate the effect of lipase on film degradation. In the absence of lipase, Films 2 and 3 exhibited weight losses of 8.6 and $18.4 \%$, respectively. These results suggested that the L-lactide segments 


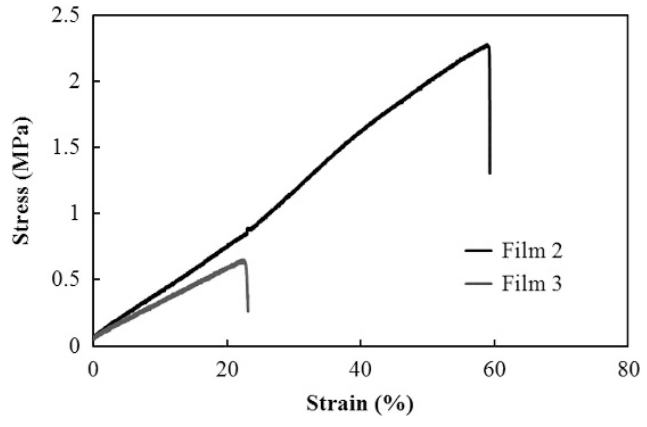

Figure 5 Stress-strain curves of Film 2 and Film 3.

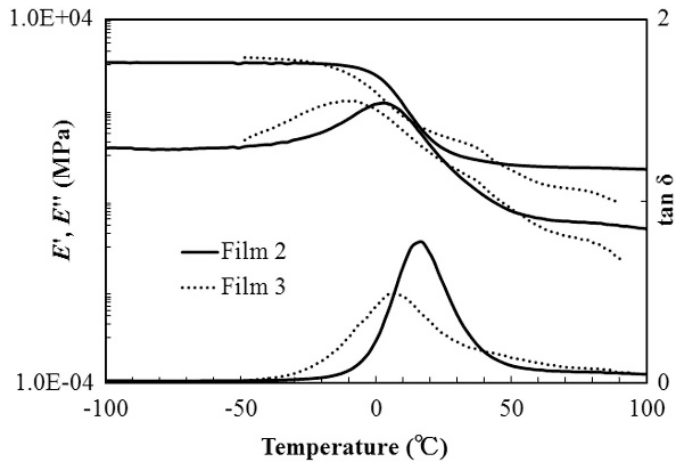

Figure 6 Temperature dependence of $E, E^{\prime}$ and $\tan \delta$ of Film 2 and Film 3.

were susceptible to degradation by phosphate buffer; however, the weight loss values were reduced in comparison with those obtained under the degradation conditions containing lipase. Because no degradation was observed for Film 1, the castor oil moiety in the polymer network was considered to be unaffected by the hydrolysis mechanisms promoted by the phosphate buffer and lipase. Because lipase is an enzyme that catalyzes the hydrolysis of triglycerides, we expected it to affect the castor oil moiety. In other words, we expected lipase to affect the triglycerides of the degradation products. Furthermore, Film 3 exhibited a higher degradability than Film 2, which was considered to be due to the lower crystallinity of the PLLA segments in Film 3 relative to Film $2 .{ }^{35}$ GPC measurements of the degradation products of Films 2 and 3 revealed the presence of soluble polymers; the peaks observed in the GPC traces were attributed to free COLA (1). In contrast, no signals were found in the GPC trace of Film 1 after exposure to the degradation conditions, which further confirmed the results from the weight loss measurement that Film 1 was not degradable. Low molecular weight degradation products, such as lactic acid likely dissolved in the phosphate buffer. For both degraded Film 2 and degraded Film 3, the ${ }^{1} \mathrm{H}$ NMR spectra of the soluble portions revealed peaks attributable to COLA at 0.9-5.6 p.p.m. Furthermore, the peaks assignable to $-\mathrm{CH}_{2} \mathrm{CH}_{2} \mathrm{Si}-$ at 0.6 p.p.m. were not observed. We therefore reasoned that the inorganic moiety remained inside the polymer network even after degradation. In addition, peaks attributable to the carboxylic acid protons derived from the degradation product were not observed in the expected range of 10-11 p.p.m. These results support the GPC measurements, which showed that degradation products dissolved in the phosphate buffer.

\section{CONCLUSION}

In conclusion, we prepared novel network polymers using castor oil and 3-(triethoxysilyl)propyl isocyanate. The obtained films were
Table 2 Weight loss and molecular weights of degraded products

\begin{tabular}{lccc}
\hline Compounds & Weight loss (\%) & $\mathrm{M}_{n}{ }^{\mathrm{a}}$ & $\mathrm{M}_{w} \mathrm{M}_{n}{ }^{\mathrm{a}}$ \\
\hline Film 1 & 0 & - & - \\
Film 2 & 9.2 & 3770 & 1.21 \\
Film 3 & 21.3 & 4420 & 1.24 \\
\hline
\end{tabular}

aDetermined by gel permeation chromatography in $\mathrm{N}, \mathrm{N}$-dimethylformamide based on polystyrene standards.

insoluble in organic solvents due to its cross-linked structure. In descending order, the thermal stability $\left(T_{\mathrm{d} 10}\right)$ of the three films was determined to be: Film $1\left(298^{\circ} \mathrm{C}\right)>$ Film $3\left(223^{\circ} \mathrm{C}\right)>$ Film 2 $\left(200^{\circ} \mathrm{C}\right)$. The interaction of the L-lactide segments increased the mechanical strength of the resultant film, while the presence of silsesquioxane moieties decreased the mechanical strength. Films 2 and 3 exhibited $T_{\mathrm{g}} \mathrm{s}$ below room temperature. Collectively, these results confirm the high thermomechanical properties of Film 2. As such, we expect Film 2 to be useful in soft material applications, such as elastomers and synthetic leather. In addition, the degradability of the polymer films in the presence of lipase was confirmed. After 30 days of degradation time, the weights of both Film 2 and Film 3 decreased significantly, while Film 1 did not exhibit any weight loss.

\section{CONFLICT OF INTEREST}

The authors declare no conflict of interest.

\section{ACKNOWLEDGEMENTS}

We are grateful to Professor H. Honma, Kanto Gakuin University Materials and Surface Engineering Research Institute, Yokohama, Japan, for his helpful comments. We are grateful to Dr N. Takahashi, Kanto Gakuin University Yokohama, Japan, for determining the crystallinity of the samples. We thank Itoh Oil Chemicals for providing castor oil. This work was partly supported by a MEXT-Supported Program for the Strategic Research Foundation at Private Universities, 2012-2016.

1 Nagata, M. \& Sato, Y. Synthesis and properties of photocurable biodegradable multiblock copolymers based on poly( $\varepsilon$-caprolactone) and poly(L-lactide) segments. J. Polym. Sci. A Polym. Chem. 43, 2426-2439 (2005).

2 Petrović, Z. S., Guo, A. \& Zhang, W. Structure and properties of polyurethanes based on halogenated and nonhalogenated soy-polyols. J. Polym. Sci. A Polym. Chem. 38, 4062-4069 (2000)

3 Yamaguchi, S., Tanha, M., Hult, A., Okuda, T., Ohara, H. \& Kobayashi, S. Green polymer chemistry: lipase-catalyzed synthesis of bio-based reactive polyesters employing itaconic anhydride as a renewable monomer. Polym. J. 46, 2-13 (2014).

4 Hosoda, N., Tsujimoto, T. \& Uyama, H. Biopolymers, bio-related polymer materials plant oil-based green composite using porous poly(3-hydroxybutyrate). Polym. J. 46, 301-306 (2014).

5 Murakami, S. \& Aoki, N. Synthesis and ring-oligomer recovery of an environmentally benign malate-containing polyurethane using enzymatic process. Kobunshi Ronbunshu 70, 565-571 (2013).

6 Kaczmarek, H., Nowicki, M., Vuković-Kwiatkowska, I. \& Nowakowska, S. Crosslinked blends of poly(lactic acid) and polyacrylates: AFM, DSC and XRD studies. J. Polym. Res. 20, 91 (2013).

7 Marubayashi, H., Asai, S., Hikima, T., Takata, M. \& Iwaki, T. Biobased copolymers composed of L-lactic acid and side-chain-substituted lactic acids: synthesis, properties, and solid-state structure. Macromol. Chem. Phys. 214, 2546-2561 (2013).

8 Hadano, M., Yamaguchi, T., Otsuka, H., Aoi, K., Sasaki, S. \& Takahara, A. Characterization and degradation behavior of segmented poly(urethaneurea)s prepared from lysine-based diisocyanate. Nippon Gomu Kyokaishi 79, 219-224 (2006).

9 Kojio, K. Research and development trend of biomass-based polyurethanes. Nippon Gomu Kyokaishi 86, 176-180 (2013).

10 Yokoe, M., Aoi, K. \& Okada, M. Biodegradable polymers based on renewable resources. VII. Novel random and alternating copolycarbonates from 1,4:3,6-dianhydrohexitols and aliphatic diols. J. Polym. Sci. A Polym. Chem. 41, 2312-2321 (2003).

11 Mülhaupt, R. Green polymer chemistry and bio-based plastics: dreams and reality. Macromol. Chem. Phys. 214, 159-174 (2013).

12 Sharma, V. \& Kundu, P. P. Condensation polymers from natural oils. Prog. Polym. Sci. 33, 1199-1215 (2008). 
13 Ristić, I. S., Marinović-Cincovic, M., Cakić, S. M., Tanasić, L. M. \& Budinski-Simendić, J. K. Synthesis and properties of novel star-shaped polyesters based on I-lactide and castor oil. Polym. Bull. 70, 1723-1738 (2013).

14 Tsujimoto, T., Haza, Y., Yin, Y. \& Uyama, H. Synthesis of branched poly(lactic acid) bearing a castor oil core and its plasticization effect on poly(lactic acid). Polym. J. 43, 425-430 (2011).

15 Miao, S., Zhang, S., Su, Z. \& Wang, P. A novel vegetable oil-lactate hybrid monomer for synthesis of high-Tg polyurethanes. J. Polym. Sci. A Polym. Chem. 48, 243-250 (2010).

16 Yachi, R. \& Kouzai, H. Synthesis and properties of novel polyurethane from plant-based materials. Mater. Sci. Tech. Jpn 48, 177-181 (2011).

17 Kamei, M., Kuratani, K. \& Kouzai, H. Synthesis of novel polyurethanes by castor oil. Mater. Raifu Gakkaishi 20, 156-159 (2008).

18 Uchida, N. \& Kouzai, H. Synthesis of novel polyurethane with ricinoleic acid. Mater. Sci. Tech. Jpn 51, 213-216 (2014).

19 Uchida, N. \& Kouzai, H. Synthesis of novel UV-curable resin using castor oil with 2acryloyloxyethyl isocyanate. Kobunshi Ronbunshu 72, 76-81 (2015).

20 Minegishi, S., Tsuchida, S., Sasaki, M., Kameyama, A., Kudo, H. \& Nishikubo, T. Synthesis of polyphosphonates containing pendant chloromethyl groups by the polyaddition of bis(oxetane)s with phosphonic dichlorides. J. Polym. Sci. A Polym. Chem 40, 3835-3846 (2002).

21 Nakabayashi, N. \& Kanda, K. Synthesis of phosphoric compounds and their adhesives to bovine teeth. Kobunshi Ronbunshu 45, 91-96 (1988).

22 Sakagami, Y., Horiguchi, K., Narita, Y., Sirithep, W., Morita, K. \& Nagase, Y. Syntheses of a novel diol monomer and polyurethane elastomers containing phospholipid moieties. Polym. J. 45, 1159-1166 (2013).

23 Maehara, T., Ohshita, J., Taketsugu, R., Hino, K. \& Kunai, A. Hydrosilylation polymerization for the synthesis of organosilicon polymers containing adamantane units. Polym. J. 41, 973-977 (2009).

24 Kuratani, K., Hasegawa, S., Katsumata, T. \& Kouzai, H. Synthesis of phosphate esters containing polymers having mesogenic group in the side chains. Kobunshi Ronbunshu 65, 188-191 (2008).
25 Tanaka, K. \& Chujo, Y. Material development of the network polymer and silicon-based hybrid polymer. J. Netw. Polym. Jpn 32, 233-244 (2011).

26 Nagafuchi, K., Kashio, M., Sugizaki, T. \& Moriya, O. Synthesis of amphiphilic and thermoresponsive polysilsesquioxane through ring opening reaction of succinimide group. Kobunshi Ronbunshu 72, 48-56 (2015).

27 Takamura, N. Okonogi, H. Gunji, T. \& Abe, Y. Preparation and properties of polysilsesquioxanes preparation and properties of polymer hybrids from vinyltrimethoxysilane. Kobunshi Ronbunshu 54, 198-207 (2000).

28 Karadag, K., Onaran, G. \& Sonmez, H. B. Polymer synthesis and reactions synthesis of crosslinked poly(orthosilicate)s based on cyclohexanediol derivatives and their swelling properties. Polym. J. 42, 706-710 (2010)

29 Niida, K., Yamaguchi, M., Kashio, M., Sugizaki, T., Moriya, O. \& Kageyama, T. Polysilsesquioxane having glycidyl group as a new hybrid adhesive material. J. Adhes. Soc. Jpn 46, 203-208 (2010).

$30 \mathrm{Kim}, \mathrm{K}$., Ogoshi, T. \& Chujo, Y. Controlled polymer hybrids with ladderlike polyphenylsilsesquioxane as a template via the sol-gel reaction of phenyltrimethoxysilane. J. Polym. Sci. A Polym. Chem. 43, 473-478 (2005).

31 Sugizaki, T., Kashio, M., Kimura, A., Yamamoto, S. \& Moriya, O. Graft polymerization of polysilsesquioxane containing chloromethylphenyl groups by atom transfer radical polymerization. J. Polym. Sci. A Polym. Chem. 42, 4212-4221 (2004).

32 Lin, Y., Pramoda, K. P., He, C., Chen, W. \& Chung, T. S. Synthesis of poly (phenylsilsesquioxane) having organostannyl groups. J. Polym. Sci. A Polym. Chem. 39, 2215-2133 (2001)

33 Tsujimoto, T., Uyama, H. \& Kobayashi, S. Green nanocomposites from renewable resources: biodegradable plant oil-silica hybrid coatings. Macromol. Rapid Commun. 24, 711-714 (2003).

34 Nanbu, S. \& Kuraoka, K. Preparation and characterization of silica/poly (butylenes succinate-co-adipate) organic-inorganic hybrid biodegradable materials by sol-gel method. J. Pac. Sci. Technol. 18, 331-340 (2009).

35 Inoue, Y. Research and Development for Green Plastics 154 (CMC Publishing, Japan, 2002) 